MABR

6,2

\section{8}

Received 2 April 2020 Revised 16 July 2020 10 September 2020 30 September 2020 6 October 2020 Accepted 7 October 2020

\title{
Assessment of port environmental protection in Taiwan
}

\author{
Po-Hsing Tseng \\ Department of Shipping and Transportation Management, \\ National Taiwan Ocean University, Keelung, Taiwan, and \\ ManWo Ng \\ Old Dominion University, Norfolk, Virginia, USA
}

\begin{abstract}
Purpose - There are many different pollution reduction strategies even within different ports in the same country. Every port can learn from these environmental protection strategies. What remains universally key, though, is to select the optimum strategy to reduce pollution. This paper aims to use a fuzzy analytic hierarchy process (FAHP) to prioritize the relative weights of key criteria assessing the port environmental protection and select the best port in Taiwan.

Design/methodology/approach - Four criteria and eleven sub-criteria of the FAHP model are developed through expert interviews and relevant literature review. Three alternative ports considered are Kaohsiung, Keelung and Taichung. The expert questionnaire samples (23) include four groups: shipping operators, port operators, governmental officials and academics.

Findings - Results indicate that finance is the most important evaluation criteria, followed by port environmental policy, technology and stakeholders. Among the three ports compared, Kaohsiung Port is selected as the best port, followed by Keelung and Taichung Port.

Originality/value - The result of this paper can help fill the gap in the existing literature regarding decision analysis techniques for port pollution regulation and expect to present a holistic picture of the important evaluation criteria related to port environmental protection as well as raise issues of public awareness concern and consequently improve green port sustainability.
\end{abstract}

Keywords Fuzzy analytic hierarchy process, Environment, Pollution, Port

Paper type Research paper

\section{Introduction}

Growing shipping and ports traffic activities play a key role in global economic development, however, they bring pollution and adverse public health impacts to the surrounding port area, and pose social and environmental challenges during construction and operation periods (Wang et al., 2018; Wang et al., 2019). These negative externalities and social costs can occur in building, repair, breaking and recycling of ships, loading/unloading operations, storing and warehousing, dredging, accidents (e.g. oil spills and ship scrapping), anti-fouling pollution, waste disposal and so on.

Past studies have analyzed the pollution issues of port-related operations (Liu et al., 2014; Barnes-Dabban et al., 2017; Casazza et al., 2019; Luna et al., 2019). For example, Zhou et al. (2020) investigated port-related emissions, environmental impact and their implication on green traffic policy in Shanghai and found the emission of container trucks are much higher

Maritime Business Review Vol. 6 No. 2,2021 pp. $188-203$

Emerald Publishing Limited 2397-3757

DOI 10.1108/MABR-04-2020-0022

(C) Pacific Star Group Education Foundation. Licensed re-use rights only.

This research is funded by Ministry of Science and Technology in Taiwan (MOST 105-2410-H035-030). 
than that of cargo-handling equipment. Munim et al. (2020) explored the green port management in the Indian Ocean Rim (including Bangladesh, Sri Lanka and Tanzania) based on Analytic Network Process and Best-Worst methods. Results found increasing privatization in port governance would improve green port management. Moeis et al. (2020) studied sustainability assessment of the Tanjung priok port cluster. The findings indicated that free trade policy and shore power system program policies can maximize the economy and reduce environmental damage. Also, several studies have evaluated the green port policies in Taiwan (Tseng and Pilcher, 2015; Tseng and Pilcher, 2016; Chang and Jhang, 2016; Tsai et al., 2018). Most of these studies have focused on energy saving or emission reducing strategies, such as reducing speed, fuel transfer, emission tax and shore power system adoption (Innes and Monios, 2018). In Taiwan, different port authorities have implemented various environmental protection strategies [1]. It is important to identify what kinds of environmental protection work best so that others can follow similar approaches. In addition, a total of three ports are studied, thus providing a more complete picture of how a country as a whole approaches the achievement of minimum port pollution and green port implementation (Rossi et al., 2013). To develop an effective decision evaluation model, the purpose of this paper adopts a fuzzy analytic hierarchy process (FAHP) to survey this issue in a novel way for the field. The findings of this paper can help construct the establishment of implementation port environmental protection policies and help effectively re-organize resource allocation and environmental programs among private, public and stakeholder divisions.

\section{Literature review}

\subsection{Main Port pollution sources}

Pollutions from port activities might have many complex sources. In this paper, three main sources (air pollution, water pollution and soil and sediment) are described [2].

2.1.1 Air pollution. For air pollution, emissions (e.g. $\mathrm{SO}_{2}$ ) might be emitted from trucks and ships around the port area (Cullinane and Cullinane, 2013; Miluse and Beatriz, 2015). These can affect people's health (e.g. lung cancer) and air quality around the port due to their urbanized character. To reduce this pollution, some regulation policies (e.g. emission control areas (ECA), LNG or bio fuels, shore power (also called cold ironing) technologies, sulphur content regulation of marine fuel are widely implemented in various ports in the world (Olcer and Ballini, 2015).

2.1.2 Water pollution. Water pollution of port (e.g. oil pollution) is a complex challenge since a cocktail of pollutants exist and have a variety of pollutive characteristics (Liu et al., 2014; Cheniti et al., 2018; Cabrini et al., 2019; Chen et al., 2020). Yet, such pollution is often highly dangerous and can affect ecological, socioeconomic, and human health problem if it is not treated appropriately. Also, water pollution results from the expulsion of fuel oil residue, ballast water, cargo residue, waste disposal and other harmful substances being emitted from ports and ships (Lam and Notteboom, 2014). These pollution sources come from docking ships, ship building activities as well as industry activities surrounding the port area. The accumulation of harmful substances may have serious impacts on the potential spread of toxic substances, resulting in severe damage to marine ecosystems. In addition, in Port Klang (Malaysia), Sany et al. (2013) indicated heavy metal contamination might bring negative impacts due to industrial wastewater and port activities.

2.1.3 Soil and sediment. It is argued that dust might bring serious air-borne particle pollution due to the handling of substances (e.g. coal, sand, grain, and land and sediments pollution) (Erdas et al., 2015). In addition, dredging operations and disposal of dredging material can create potential soil and sediment pollution, especially in navigation channel 
MABR

6,2

Table 1.

Number of ship calls and TEU handled in three main ports in 2019 deepening and widening works. In Iran, Rastmanesh et al. (2017) indicated ecological risk assessment should be conducted in the industrial port cities.

\subsection{Overview of pollution reduction in the three main ports of Taiwan}

In Taiwan, in terms of TEU (20-ft Equivalent Unit), Kaohsiung is the largest port, followed by Keelung and Taichung (Table 1) [3]. Based on official data [4], in 2019, the above three ports served 75,717 ship calls and handled 15,298,291 TEU.

To improve port environmental problems, Environmental Protection authorities and Taiwan International Ports Corporation (TIPC) have adopted various strategies (e.g. Taiwan Greening the Ports Action Plan [5]) in the operation district of the port to control and reduce negative impacts, such as shore power system, dust prevention nets, high water pressure car wash land, automatic spraying system, automatic gates, dredging management, vessel speed reduction, energy consumption management, port waste management, education training for pollution awareness, etc.

\subsection{Key criteria for evaluating port environmental protection}

2.3.1 Port environment policy criteria. Port environmental policy is understood to mean the pollution regulation rules from international maritime conventions (e.g. MARPOL)/central competent authority/local law enforcement agency [6]). Some key international maritime conventions are International Convention for the Prevention of Pollution from Ships (MARPOL) or The Clean Air Action Plan (CAAP) or low-sulphur limits of the Emission Control Areas (ECA) (Cullinane and Cullinane, 2013; Liu et al., 2014; Zhen et al., 2018; Tseng and Pilcher, 2019). To supplement the regulatory scope of international maritime conventions, each country's ports have themselves established strict local rules of pollution prevention and have specified environment standards based on the various characteristics of specific port areas (Cullinane and Cullinane, 2013). Further, some researchers suggested a cap-and-trade mechanism can be implemented to control air pollution around the port (Mellin and Rydhed, 2011; Cullinane and Cullinane, 2013). In such schemes, a cap is set on total emissions and divided into permits which are given for free, or auctioned out to participants in the market. The participants could trade their permits. However, it is argued that pollution producers with high abatement costs could exchange permits from pollution producers with low abatement cost. Lam and Notteboom (2014) indicated that minimum environmental standards for port environment regulations require incentives mechanism and technical assistance. It is believed that International Maritime Organization (IMO) should provide greater guidelines from key bodies (Lam and Notteboom, 2014). Indeed, research shows that some countries have allocated human and other resources to gain environmental certification and such efforts were thought to be excessive [e.g. Poland (Klopott, 2013)]. Furthermore, integrative coordination in a country can help improve implementation and ultimately improve marine water quality, and research shows this has happened in Taiwan when coordination between ports is integrated (Ko and Chang, 2010). In Taichung (Taiwan), Tsai et al. (2018) adopted self-management approach to estimate the

\begin{tabular}{lccrr}
\hline Port & No. of ship calls & $(\%)$ & No. of TEU & $(\%)$ \\
\hline Keelung & 22,606 & 30.0 & $3,075,685$ & 20.1 \\
Taichung & 17,492 & 23.0 & $1,793,966$ & 11.7 \\
Kaohsiung & 35,619 & 47.0 & $10,428,634$ & 68.2 \\
Total & 75,717 & 100.0 & $15,298,291$ & 100.0 \\
\hline
\end{tabular}


potential reduction of air pollution emission. Linder (2018) indicated policy incentive might affect the shipping company to participate voluntary vessel emission reduction project.

2.3.2 Technology criteria. Technology means the various solutions or techniques to regulate and mitigate against the negative impacts on port development. Here, technology can be separated into anti-pollution equipment and facilities, environmental sensors and green energy research (Liu et al., 2019). First, some anti-pollution clean energy equipment and facilities are used to reduce port's various pollutions and expect to fit the requirement of energy regulation rule (e.g. Energy Efficiency Design Index), such as seawater scrubbers Port environmental protection in Taiwan and filters, cold ironing, automatic gate systems, low emission trucks, high water pressure car wash lane, dust prevention net, automatic spraying system, covered warehouse facility and sealed storage, (Innes and Monios, 2018). Further, it is believed that adopting efficient and fuel-saving cargo-handling equipment can result in reduced environmental damage used in green ports in many countries (Subasi and Dogan-Saglamtimur, 2013). Subasi and Dogan-Saglamtimur (2013) found that adequate waste reception facilities can effectively reduce and eliminate ship-generated pollution in the port area. In addition, Satir (2014) stated ballast water treatment systems (BWTSs) is a useful method to reduce water pollution and proposed an effective management mechanism. Second, environmental sensors have been used to monitor ships' operation activities to reduce environmental impact (e.g. air quality and noise). For example, it is well known that reducing a ship's speed can reduce fuel consumption and emissions. Thus, it has been suggested that establishing effective environmental sensors (e.g. vessel traffic system and automatic identification system) to monitor and control air pollution, noise pollution, sludge, ecology, water quality (Wang et al., 2019) would be effective. Finally, green energy research has involved technical development for fuel oil residue, waste disposal and ballast water (Lam and Notteboom, 2014). Port data collection and analysis (including ships and cargoes) is necessary since it helps identify potential solutions to environmental issues (Darbra et al., 2009) . For example, Liu and Tsai (2011) suggested that ballast water and traffic pattern analysis of ships can be well implemented to control and reduce the risk of introducing non-indigenous aquatic species. Thus, here a key need for technical sources assistance should be supported.

2.3.3 Finance criteria. Financial is defined as using a "carrot and stick" method to regulate and maintain the port environment (Lam and Notteboom, 2014). Here, financial areas can be categorized into port pricing, supporting incentives and voluntary incentives. In Taiwan, TIPC issues NT 8,000 bonus a ship every time the ship meets the vessel speed reduction criteria both entering and exiting the port. For example, port pricing can be used to encourage port users to reduce pollution based on user pay principles (Tseng and Pilcher, 2019). Bergqvist and Egels-Zandén (2012) suggested that introduction of a hinterland port dues system could reduce port pollution from shipping operations. In addition, supporting incentives mean port authorities could provide financial and technical support to help port users use energy saving equipment or facilities in the port area (Blinge, 2014). Understandably, many solutions have been suggested to help mitigate against such pollutive activities and to improve port sustainability (Tseng and Pilcher, 2015). Therefore, for port authorities, it is arguably effective to conduct voluntary incentives and encourage port users to use environment friendly methods and then obtain port concession.

In general, both "carrot"-type incentives and "stick"-type punitive pricing can be adopted simultaneously (Tseng and Pilcher, 2019). In addition, it is often the case that economic and financial implications are connected to the fact that Labor Unions will be involved in any introduction of green port policies and this in turn will, it has been argued, increase the cost burden for shipping operators. In a case study of Kaohsiung Port, Liu et al. (2014) suggested the port authroities should use cold ironing alongside 'carrot and stick' approaches to reduce 
MABR

6,2
$\mathrm{SO}_{2}$ emissions. Greiner (2014) has also suggested market-based instruments are useful tools to regulate water quality in coastal waterways.

2.3.4 Stakeholder criteria. The term stakeholder is understood to denote people who are closely related to port activities and includes governmental officials, port operators, shipping operators and community residents (Hall et al., 2013). In Taiwan, governmental officials are port policymakers and can establish environmental criteria and concession agreements in the port and alter terminal operators/shipping operators' behaviour, such as Maritime and Port Bureau (MPB). Other stakeholders, such as community groups, shipping agents, fishers, ocean resource researchers, legislators, environmental group(Environmental Protection Administration, Environmental Protection Bureau, academia, ship construction operators, could provide suggestions to improve port pollution problems (Ghashat and Cullinane, 2013). Le et al. (2014) noted that all stakeholders must be involved to achieve engagement in any policy.

\subsection{Summary}

Based on the above literature reviews, four key criteria and eleven sub-criteria affecting port environmental protection are summarized in Table 2.

\section{Methodology}

\subsection{Research design of fuzzy analytic hierarchy process}

Saaty (1980) initially developed the analytic hierarchy process (AHP) to solve decisionmaking analysis problems. Based on the assumption that criteria and independent, it provided a systematic hierarchy structure and its ratio scales can be utilized to make reciprocal comparisons for each element and layer. However, traditional AHP exists some limitations due to it cannot fully represent the decision makers' ideas. For example, expert's judgment might entail subjectivity and ambiguity and unavoidably exist uncertainty. According to Zadeh (1965), this paper adopts fuzzy linguistic variables with corresponding fuzzy triangular numbers to conduct comparison analysis among the many elements included. Such a method can help to solve uncertain or vague problems when implementing criteria assessment and decision-making analysis (Ferdous et al., 2012; Goyal et al., 2018; Liu et al., 2019) and is better than traditional AHP method.

A triangular fuzzy number with the member function is shown in Figure 1. [7] Based on Zadeh (1965), the membership function is described by the triplet (1, $\mathrm{m}, \mathrm{u}$ ) as in equation (1):

$$
U \tilde{M}(x)=\left\{\begin{array}{c}
\frac{(x-l)}{(m-l)}, l \leq x \leq m \\
\frac{(u-x)}{(u-m)}, m \leq x \leq u \\
0, \text { others }
\end{array}\right.
$$

where $m$ is the most possible value of the fuzzy number $U \tilde{M}(x), \tilde{M}(x)$ is a triangular fuzzy number., 1 and $u$ represent the minimum and maximum values, respectively:

$$
\begin{gathered}
\mathrm{M} 1=(11, \mathrm{~m} 1, \mathrm{u} 1) \text { and } \mathrm{M} 2=(12, \mathrm{~m} 2, \mathrm{u} 2) \text { are } \\
\mathrm{M} 1+\mathrm{M} 2=\left(\mathrm{l}_{1}+\mathrm{l}_{2}, \mathrm{~m}_{1}+\mathrm{m}_{2}, \mathrm{u}_{1}+\mathrm{u}_{2}\right)
\end{gathered}
$$




\begin{tabular}{|c|c|c|c|}
\hline Criteria & Sub-criteria & Description & Sources \\
\hline \multirow[t]{3}{*}{$\begin{array}{l}\text { Port } \\
\text { environmental } \\
\text { policies }\end{array}$} & $\begin{array}{l}\text { International } \\
\text { maritime } \\
\text { convention } \\
\text { (F11) }\end{array}$ & $\begin{array}{l}\text { Maritime pollution regulation } \\
\text { convention e.g. MARPOL, Emission } \\
\text { Control Areas (ECA) }\end{array}$ & $\begin{array}{l}\text { Cullinane and Cullinane (2013), } \\
\text { Lam and Notteboom (2014); Liu } \\
\text { et al. (2014), Zhen } \text { et al. (2018); Zhu } \\
\text { et al. (2018), Tseng and Pilcher } \\
\text { (2019) }\end{array}$ \\
\hline & $\begin{array}{l}\text { Local rules of } \\
\text { pollution } \\
\text { prevention } \\
\text { (F12) }\end{array}$ & $\begin{array}{l}\text { Local port authorities set minimum } \\
\text { pollution standard for port operator }\end{array}$ & $\begin{array}{l}\text { Cullinane and Cullinane (2013), } \\
\text { Lam and Notteboom (2014) }\end{array}$ \\
\hline & $\begin{array}{l}\text { Voluntarily- } \\
\text { monitoring } \\
\text { mechanism } \\
\text { (F13) }\end{array}$ & $\begin{array}{l}\text { Port authorities and operators } \\
\text { regularly conduct pollution check } \\
\text { and monitoring works }\end{array}$ & Linder (2018), Tsai et al. (2018) \\
\hline \multirow[t]{3}{*}{ Technology } & $\begin{array}{l}\text { Anti-pollution } \\
\text { equipment and } \\
\text { facilities (F21) }\end{array}$ & $\begin{array}{l}\text { Adopting anti-pollution equipment } \\
\text { and facilities to reduce } \\
\text { environmental pollution, such as } \\
\text { modernized equipment of cargo } \\
\text { handling, sulphur scrubber, air } \\
\text { lubrication, hull coating, etc. }\end{array}$ & $\begin{array}{l}\text { Subasi and Dogan-Saglamtimur } \\
\text { (2013), Olcer and Ballini (2015); } \\
\text { Innes and Monios (2018), Chen } \text { et al. } \\
\text { (2019); Peng } \text { et al. (2019) }\end{array}$ \\
\hline & $\begin{array}{l}\text { Environmental } \\
\text { sensors (F22) }\end{array}$ & $\begin{array}{l}\text { Using monitoring technologies to } \\
\text { regulate port pollution producers, } \\
\text { such as vessel traffic system }\end{array}$ & $\begin{array}{l}\text { Bjerkan and Seter (2019), Tseng } \\
\text { and Pilcher (2019) }\end{array}$ \\
\hline & $\begin{array}{l}\text { Green energy } \\
\text { research (F23) }\end{array}$ & $\begin{array}{l}\text { Investment in green energy } \\
\text { research and development, such as } \\
\text { biofuels, nuclear power, hydrogen, } \\
\text { wind and solar technologies }\end{array}$ & $\begin{array}{l}\text { Cullinane and Cullinane (2013), } \\
\text { Erdas et al. (2015); Liu et al. (2019) }\end{array}$ \\
\hline \multirow[t]{3}{*}{ Finance } & $\begin{array}{l}\text { Port pricing } \\
\text { (F31) }\end{array}$ & $\begin{array}{l}\text { Using port pricing strategies to } \\
\text { shorten terminal operation time and } \\
\text { then reduce pollution. }\end{array}$ & $\begin{array}{l}\text { Cullinane and Cullinane (2013), } \\
\text { Lam and Notteboom (2014); Tseng } \\
\text { and Pilcher (2019) }\end{array}$ \\
\hline & $\begin{array}{l}\text { Supporting } \\
\text { incentives } \\
\text { (F32) }\end{array}$ & $\begin{array}{l}\text { Investments in port infrastructure } \\
\text { to increase operation efficiency, } \\
\text { such as support for anti-pollution } \\
\text { facilities. }\end{array}$ & $\begin{array}{l}\text { Bergqvist and Egels-Zandén (2012); } \\
\text { Lam and Notteboom (2014), Blinge } \\
\text { (2014); Innes and Monios (2018), } \\
\text { Lam and Li (2020) }\end{array}$ \\
\hline & $\begin{array}{l}\text { Voluntary } \\
\text { incentives } \\
\text { (F33) }\end{array}$ & $\begin{array}{l}\text { Agreements to use environment } \\
\text { friendly method ) to reduce } \\
\text { pollution and then obtain port } \\
\text { concession }\end{array}$ & $\begin{array}{l}\text { Lam and Notteboom (2014), Blinge } \\
\text { (2014); Tseng and Pilcher (2015), } \\
\text { Tsai et al. (2018); Hua et al. (2020) }\end{array}$ \\
\hline \multirow[t]{3}{*}{ Stakeholder } & $\begin{array}{l}\text { Governmental } \\
\text { officials (F41) }\end{array}$ & $\begin{array}{l}\text { Governmental officials in port } \\
\text { authorities }\end{array}$ & $\begin{array}{l}\text { Ghashat and Cullinane (2013), Le } \\
\text { et al. (2014) }\end{array}$ \\
\hline & $\begin{array}{l}\text { Port operators } \\
\text { (F42) }\end{array}$ & $\begin{array}{l}\text { Cargo-handling equipment } \\
\text { conductor, stevedore operators, } \\
\text { terminal manager, truck driver }\end{array}$ & $\begin{array}{l}\text { Ghashat and Cullinane (2013), Le } \\
\text { et al. (2014) }\end{array}$ \\
\hline & $\begin{array}{l}\text { Shipping } \\
\text { operators(F43) }\end{array}$ & $\begin{array}{l}\text { Liner and tramp shipping } \\
\text { companies }\end{array}$ & $\begin{array}{l}\text { Mellin and Rydhed (2011), Le } \text { et al. } \\
\text { (2014); Tseng and Pilcher (2019) }\end{array}$ \\
\hline
\end{tabular}

Notes: There are many stakeholders (e.g. government, employee, clients, community groups, legislators, environmental group, academia, etc.) that involve port pollution policies. We summarize three key roles (including governmental officials, port operators, shipping operators) based on main past studies

environmental

protection in

Taiwan

193

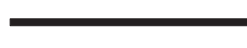


MABR

6,2

$$
\begin{gathered}
\mathrm{M} 1 \times \mathrm{M} 2=\left(\mathrm{l}_{1}+\mathrm{l}_{2}, \mathrm{~m}_{1}+\mathrm{m}_{2}, \mathrm{u}_{1}+\mathrm{u}_{2}\right) \\
\beta \times M_{1}=\left(\beta_{l 1}, \beta_{m 1}, \beta_{u 1}\right), \beta>0, \beta \in R \\
M^{-1}=(l, m, u)^{-1}=\left(\frac{1}{u}, \frac{1}{m}, \frac{1}{l}\right)
\end{gathered}
$$

Thence, based on fuzzy pairwise comparison matrices (Chang, 1996), fuzzy logic is introduced to solve the uncertainness of AHP analysis.

In this paper, 28 expert samples were chosen by convenience sampling and these experts separately contacted by email or telephone and asked if they were able to take part in the questionnaire survey. The background of these experts were reviewed (e.g. 10 related working and research experiences at least) to make sure they are qualified experts and have sufficient port pollution knowledge. Measurement scale/comparison of elements is a ninepoint rating. It is designed to measure the experts' perceptions of what was relatively "important" and "unimportant". Also, a consistency index $(\mathrm{Cl})$ is used to test any inconsistency within experts' judgments (Saaty, 1980). In addition, a consistency ratio (CR) is further adopted to test how a given matrix compares to a random matrix in terms of the $\mathrm{CI}$, as shown in equations (6) and (7):

$$
\begin{gathered}
C I=\frac{\theta_{\max }-n}{n-1} \\
C R=\frac{C I}{R I}
\end{gathered}
$$

where $C I$ represents the consistency index; $\theta_{\max }$ presents the maximum eigenvalue of the positive reciprocal matrix. $R I$ represents a randomized index and $n$ is the number of criteria in the matrix. All $C R$ values are $\leqq 0.1$ (Saaty, 1980).

\subsection{The proposal fuzzy analytic hierarchy process model}

In this paper, four criteria include port environmental policy, technology, finance and stakeholders. To validate the measures, during 1-15 December 2017, five experts in the field were invited to pre-test and refine questionnaire to improve its wording and readability [8].

Figure 1.

Triangular fuzzy number

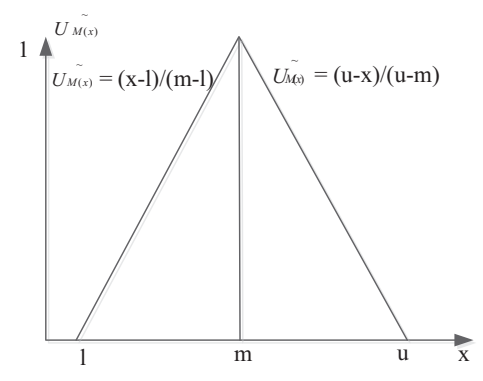




\section{Results}

\subsection{Data collection}

Before sending the questionnaire, we interviewed three senior port experts to conduct content validity of questionnaire [9]. Then we reviewed 28 potential samples' backgrounds (including senior shipping operators (7), senior port operators (7), senior governmental officials (7) and academics (7) to confirm they are qualified candidates to participate the questionnaire survey [10]. On 1 January 2018, 28 questionnaires were sent to samples [11] and 28 questionnaires replies had been received on 21 January 2018. Then the CI was individually checked to confirm the consistency of pairwise comparison matrix. In total, five questionnaires were discarded because they exist highly inconsistent due to CI $>0.1$ (Saaty, 1980). Therefore, the effective questionnaire response rate was $82.1 \%(=23 / 28)$.

Table 3 showed 23 samples' characteristics (including six port operators, five shipping operators, six governmental officials and six academics). Regarding shipping/port experts/ academics, most of these experts have 16 years' experiences. Their job titles are supervisor or assistant professor (or above).

\subsection{Fuzzy analytic hierarchy process analysis}

Analysis results of fuzzy AHP is shown in Table 4 shows that finance $(0.283)$ is the most important criteria, followed by port environmental policy (0.274), technology (0.226), and stakeholders (0.217). With regard to the sub-criteria, voluntarily monitoring mechanism (0.346), anti-pollution equipment and facilities (0.362), supporting incentives (0.361), and shipping operators $(0.379)$ were the most important sub-criteria in terms of each criteria for port environmental policy, technology, finance, and stakeholders, respectively.

Furthermore, the analysis results indicated that supporting incentives (0.102), port pricing (0.098) and local rules of pollution prevention (0.095) are the top three important criteria affecting port environmental protection.

Finally, Table 5 indicated that Kaohsiung Port (0.400) was selected as the best port with the best port environmental protection, followed by Keelung (0.311) and Taichung (0.289), respectively. Kaohsiung Port has the highest score in terms of port environment policy, technology and finance criteria. Overall, Kaohsiung Port is ranked as the best port due to its higher weight score. Keelung and Taichung Ports are ranked as second and third based on their weight scores. In fact, Kaohsiung is ranked as top one international commercial port in Taiwan and consequently can obtain more finance funds [12] from government related units for port pollution improvement works. Therefore, it is believed Kaohsiung Port has enjoyed a better niche market to implement pollution prevention, monitoring, and control mechanisms in and around the port areas compared to Keelung and Taichung Port.

Keelung port, the second best port in our results, has higher stakeholders score due to the reason that maybe its location is near Taipei Metropolis and many headquarters of port authorities and shipping companies can directly/indirectly bring more decision making impacts.

Actually, these three ports have different strategic positions and consequently develop various port environment protection works for their core services. For example, Keelung port has focused on Asia regional container shipping, cross-Taiwan Straits ferry services, and international cruise services. Taichung Port has dominated at free trade zone with valued-added logistics, and cross-Taiwan Strait passenger and goods transportation services. Kaohsiung Port has played a key role in international container transhipment, fullspectrum value-added logistics and international cruise services.

Regarding port regulation related works, diesel truck driver who do not possess qualified A1 A3 level certificate will be fined NT 60,000. Actually, various initiatives towards 
MABR

6,2

196

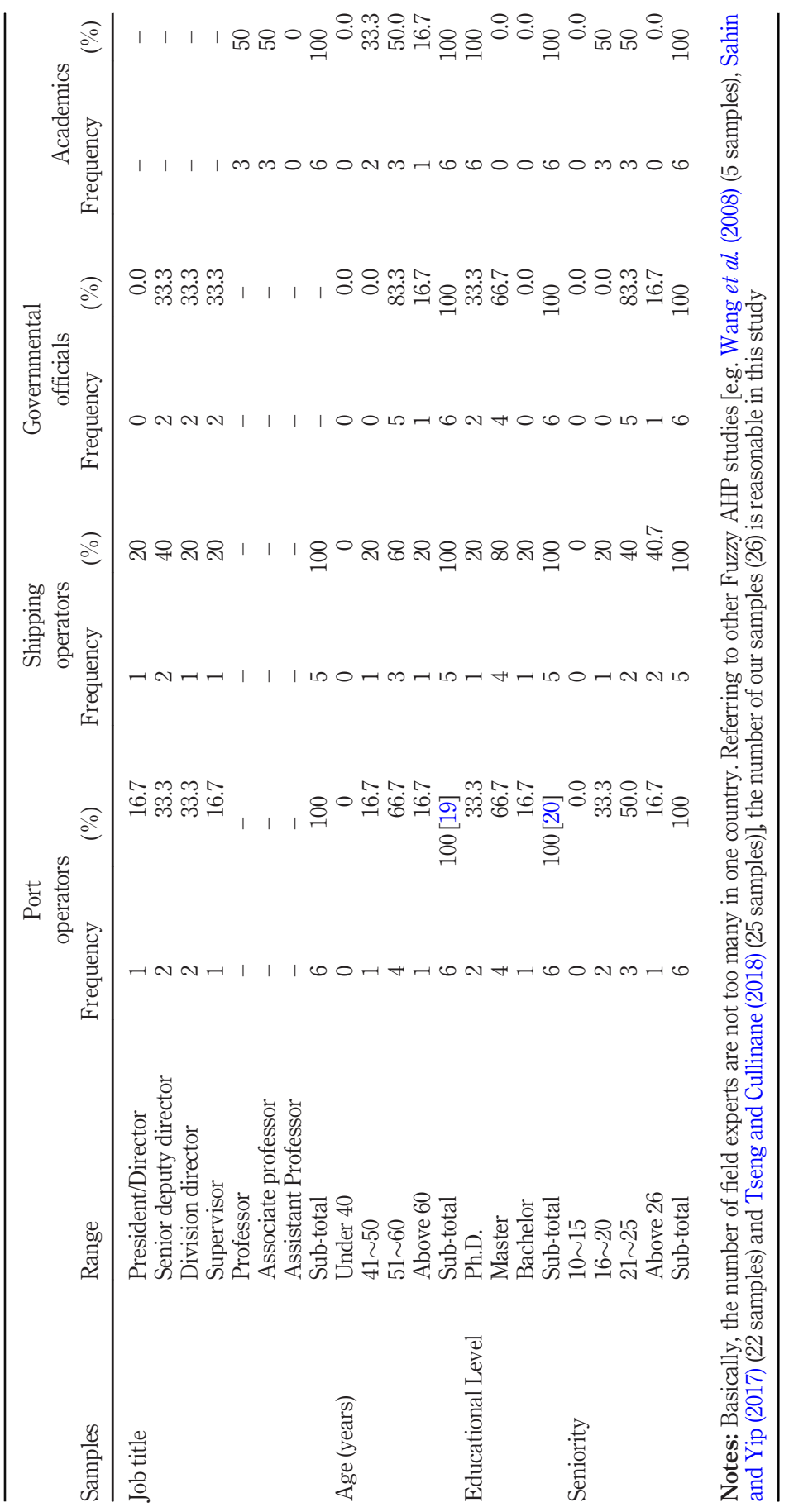

Table 3.

Profiles of the samples 


\begin{tabular}{|c|c|c|c|c|c|c|}
\hline Criteria & $\begin{array}{l}1^{\text {st }} \text { tier Local } \\
\text { weights }\end{array}$ & $\begin{array}{l}\text { Consistency } \\
\text { ratio (CR) }\end{array}$ & Sub-criteria & $\begin{array}{l}2^{\text {nd }} \text { tier Local } \\
\text { weights }\end{array}$ & $\begin{array}{l}\text { Global } \\
\text { weights }\end{array}$ & Rank \\
\hline $\begin{array}{l}\text { Port } \\
\text { Environmental }\end{array}$ & 0.274 & 0.070 & $\begin{array}{l}\text { International maritime } \\
\text { convention }\end{array}$ & 0.321 & 0.088 & 5 \\
\hline \multirow[t]{2}{*}{ Policy } & & & $\begin{array}{l}\text { Local rules of pollution } \\
\text { prevention }\end{array}$ & 0.333 & 0.091 & 4 \\
\hline & & & $\begin{array}{l}\text { Voluntarily-monitoring } \\
\text { mechanism }\end{array}$ & 0.346 & 0.095 & 3 \\
\hline \multirow[t]{3}{*}{ Technology } & 0.226 & 0.070 & $\begin{array}{l}\text { Anti-pollution equipment and } \\
\text { facilities }\end{array}$ & 0.362 & 0.082 & 7 \\
\hline & & & Environmental sensors & 0.321 & 0.073 & 10 \\
\hline & & & Green energy research & 0.317 & 0.072 & 11 \\
\hline \multirow[t]{3}{*}{ Finance } & 0.283 & 0.034 & Port pricing & 0.347 & 0.098 & 2 \\
\hline & & & Supporting incentives & 0.361 & 0.102 & 1 \\
\hline & & & Voluntary incentives & 0.292 & 0.083 & 6 \\
\hline \multirow[t]{3}{*}{ Stakeholders } & 0.217 & 0.052 & Governmental officials & 0.339 & 0.074 & 9 \\
\hline & & & Port operators & 0.282 & 0.061 & 12 \\
\hline & & & Shipping operators & 0.379 & 0.082 & 7 \\
\hline
\end{tabular}

Notes: "Local weight is derived from judgment with respect to a single indicator; ${ }^{* *}$ Global weight is derived from multiplication by the weight of each group of the 1st tier and 2nd tier local weights

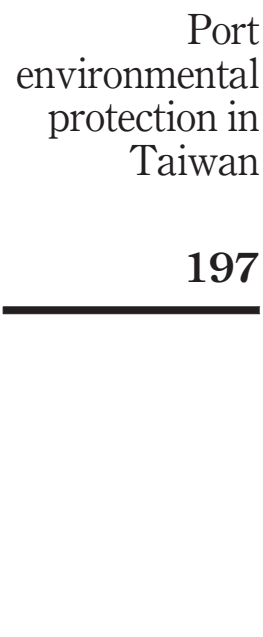

Table 4.

FAHP results

\begin{tabular}{lccccccr}
\hline Port & Port environmental policy & Technology & Finance & Stakeholders & Weight & Ranking & \\
\hline Keelung & 0.263 & 0.306 & 0.289 & 0.409 & 0.311 & 2 & Table 5. \\
Taichung & 0.367 & 0.343 & 0.237 & 0.196 & 0.289 & 3 & Summary of best \\
Kaohsiung & 0.370 & 0.351 & 0.375 & 0.395 & 0.400 & 1 & port comparison \\
\hline
\end{tabular}

pollution prevention, monitoring and control mechanisms are continuously constructed to enhance the environment quality in and around port areas (e.g. waste management, and electricity/fuel/water/paper consumption management and renewable energy). Therefore, their efforts on pollution improvement should not be ignored or dismissed even though there are some weight differences in the analysis results.

\section{Discussion and conclusion}

Results indicated finance is perceived to be the most important criterion, followed by port environmental policy, technology, and stakeholders. Among the three main ports, Kaohsiung Port is selected as being the best port due to its effective performance in environmental policy, technology and finance criteria. For example, Kaohsiung Port is equipped with sufficient container terminal resources and can offer better cargo handling efficiency (34.99 TEU per hour-crane in 2018). Thus, Taichung (30/92 TEU per hour-crane in 2018) and Keelung (24.34 TEU per hour-crane) [13] can both learn from Kaohsiung Port's development experience and improve operation efficiency. Overall, these three ports in Taiwan have successfully received Eco-Port certification (Port of Kaohsiung in October 2014, Keelung and Taichung in November 2015) [14], policy formulation and implementations (including any commercial activities [15] and cargo handling [16]) for pollution reductions. Nevertheless, as the results here show, there are arguably still many 
MABR

6,2

potential barriers even though these pollution reduction effects have been achieved in recent years.

It is suggested that port authorities should adopt automatic and green facilities (e.g. using hybrid or rail mounted gantry to replace rubber tired gantry) and adopt stricter international conventions to reduce fuel consumption and emissions, noise and related port environmental pollution problems. However, the sources of port pollution are complicated and not easily be regulated by current international maritime conventions or port rules. Therefore, some pollution mitigation strategies just can solve part of port pollutions, such as emission problem (via energy-saving facilities, fuel transfer, vessel speed reducing, etc.) (Chang and Jhang, 2016), water quality (via ballast management) (Cullinane and Cullinane, 2013). Therefore, an integrated decision analysis is needed to investigate potential problems and solutions. For example, port authorities need to balance a wide range of complex decision problems and consider stakeholders' opinions [17]. Also, finance is selected as important criteria since port environment improvement and facilities upgrade (e.g. electronic gantry cranes and clean trucks) always need significant funds, and major polluters should be levied for pollution external cost (or pollution tax) based on a Pigouvian tax [18] principle (Bergqvist and Egels-Zandén, 2012). Pollution tax must be fair for port users in a sustainable manner from the perspective of environment, society and business. However, these policy formulations and legislations are always long-term negotiation processes and require much time since they must achieve the mutual recognition from various stakeholders. In addition, as shown by the findings above, supporting incentive is selected as most important subcriteria for pollution reduction policies. Such a result can be interpreted to imply that many port environmental policies must adopt 'carrot and stick' method to encourage port users (polluters) adopt greener facilities, renewable or environmental energy (e.g. low-sulphur fuel) and automatic operation processes to reduce port pollution sources. In addition, reducing upstream pollution sources is also key. For example, port authorities (e.g. TIPC and MPB) should continuously cooperate with local governments (e.g. Environment Protection Bureau and Water Resource Management Bureau, Marine Bureau, etc.) to provide funds for constructing sustainable operation areas and waterfront spaces. It is believed the analysis model of this paper can be effectively shifted to other countries (especially in maritime-based or island-based countries, such as UK, Japan, Philippines, etc.) and develop pollution reduction approaches in similar ways. There are two research limitations and researchers can further extend other potential research topics in the future. The first is that all (sub)criteria are independent in the AHP model. Future researchers can adopt advanced quantitative analysis (e.g. fuzzy analytic network process, decision-making trial and evaluation laboratory [DEMATEL]) to resolve independences problems in similar topics, such as port of call location for liner/tramp shipping/cruise operators, port safety, port governance, etc. Second, this paper adopted a mail-based survey to collect the questionnaires and consequently might lack qualitative analysis content. Future researchers can adopt in-depth interview methods based on grounded theory with content analysis to validate and extend potential areas (e.g. argument of experts' agreement and disagreement opinions) for future research from this paper's findings.

\section{Notes}

1. There are seven international commercial ports (Keelung, Taichung, Kaohsiung, Hualien, Taipei, Suao, Anping) in Taiwan. Taipei and Suao Port are auxiliary ports of Keelung. Anping Port is an auxiliary Port of Kaohsiung. Hualien Port does not have container traffic. Therefore, only Keelung, Taichung and Kaohsiung port are selected as alternatives in this paper. 
2. Port pollutions (e.g. air pollution, water and soil pollution, sediment, port waste, dangerous material, light pollution, noise pollution, brownfield remediation due to heavy industry, etc.) come from various sources and complex. In order to focus on our research targets (scopes) which link with environmental protection strategies, these first three items (air, water and soil and sediment) were discussed. Other pollution sources can be further explored in future research topics.

3. Figures of Keelung include Taipei Port and Suan Port. Figures of Kaohsiung includes Anping Port.

4. Taiwan International Ports Corporation, Ltd. www.twport.com.tw/en/

5. www.twport.com.tw/en/cp.aspx?n=3C08FE6E60F9553F

6. These laws include Basic Environment Act, Marine Pollution Control Act, Environment Education Act, Air Pollution Control Act, Noise Control Act, Water Pollution Control Act, Environmental Impact Assessment Act, Waste Disposal Act, .

7. Triangular fuzzy number is more popular than the trazpoid number and widely used in port selection and maritime related studies (Chen, 2016).

8. Any related port policies which were implemented or revised must be consulted by various field experts. To our best knowledge, our paper was first study to assess port pollution reduction policies in Taiwan. Even the empirical survey data were conducted in January 2018, it is believed that our research findings can offer useful information and managerial implications for decision makers of port stakeholders.

9. Regarding shipping companies, we interviewed three directors who work for Yang Mine Marine Transport, Evergreen Marine Corp., and Wan Hai Lines in Taiwan. In terms of port authorities, we interviewed two directors who work for Taiwan International Ports Corporation Ltd. and Maritime and Port Bureau in Taiwan. These three interviewees have more than 32 years' practical working experiences. We further revised questionnaire content based on interviewees' comments and suggestions. Each interview averaged 30-60 minutes in length.

10. These potential samples had to have practical port operation or research experience (above 10 years at least) and have a good reputation in the field.

11. We have confirmed the expert can understand how to fill the questionnaire via Fuzzy Analytic Process via phone call before we sent the questionnaire.

12. These funds include dedicated financial budget from the governmental units (e.g. Environmental Protection Bureau, Kaohsiung City Government), anti-air pollution subsidies from the Ministry of Transportation and Communication, Environmental Protection Administration, Executive Yuan, Taiwan. https://www.epa.gov.tw/Page/7CF1232C5F0B0463

13. Annual Statistics Report, Taiwan International Ports Corporation, 2018. The figure of Keelung Port has included the Taipei Port.

14. Ministry of Transportation and Communication www.motc.gov.tw/en/ www.motc.gov.tw/en/ home.jsp?id $=158 \&$ parentpath $=0,151 \&$ mcustomize $=$ news_view.jsp\&dataserno $=201512100006 \&$ aplistdn $=$ ou=data,ou=news, ou=english,ou=ap_root,o=motc,,$=$ tw\&toolsflag $=$ Y\&imgfolder $=\#$

15. Including marinas/leisure, ship building and repair, petroleum product processing, general manufacturing, refrigerated cargo, storage and packaging, chemical industry.

16. Including dry bulk, petroleum/ oil products, general cargo, liquid bulk (non-oil) and ro-ro.

17. Governmental authorities include Ministry of Transportation and Communication, Ministry of the Interior, Council of Agriculture, Environmental Protection Administration, etc. Private operators include shipping operators, terminal operators, cargo handling operators, trucker, tugboat operators, shippers, freight forwarders, shipping agents, etc. 


\section{MABR}

6,2
18. It is a tax on any market activity that generates negative externalities (costs not included in the market price).

19. Round up figures to an approximate.

20. Round up figures to an approximate.

\section{References}

Barnes-Dabban, H., Tatenhove, J.P.M., Koppen, K. and Termeer, K. (2017), "Institutionalizing environmental reform with sense-making: West and Central Africa ports and the 'green port' phenomenon", Marine Policy, Vol. 86, pp. 111-120.

Bergqvist, R. and Egels-Zandén, N. (2012), "Green port dues-the case of hinterland transport”, Research in Transportation Business and Management, Vol. 5, pp. 85-91.

Bjerkan, K.Y. and Seter, H. (2019), "Reviewing tools and technologies for sustainable ports: does research enable decision making in ports?", Transportation Research Part D: Transport and Environment, Vol. 72, pp. 243-260.

Blinge, M. (2014), "Policy measures to realize green corridors-A stakeholder perspective", Research in Transportation Business and Management, Vol. 12, pp. 55-62.

Cabrini, M., Gerino, F., Olazabal, A., Poi, E.D., Fabbro, C., Fornasaro, D., Goruppi, A., Flander-Putrle, V., Francéb, J., Gollaschc, S., Hured, M., Lipejb, L., Lučićd, D., Magalettie, E., Mozetičb, P., Tintab, T., Tornambèe, A., Turkb, V., Uhan, J. and David, M. (2019), "Potential transfer of aquatic organisms via ballast water with a particular focus on harmful and non-indigenous species: a survey from adriatic ports", Marine Pollution Bulletin, Vol. 147, pp. 16-35.

Casazza, M., Boggia, F., Searfino, G., Severino, V. and Lega, M. (2019), "Environmental impact assessment of an urban port: noise pollution survey in the port area of Napoli (S Italy)", Journal of Environmental Accounting and Management, Vol. 6 No. 2, pp. 125-133.

Chang, D.Y. (1996), “Application of the extent analysis method on fuzzy AHP”, European Journal of Operational Research, Vol. 95 No. 3, pp. 649-655.

Chang, C.C. and Jhang, C.W. (2016), "Reducing speed and fuel transfer of the green flag incentive program in Kaohsiung Port Taiwan", Transportation Research Part D: Transport and Environment, Vol. 46, pp. 1-10.

Chen, Y., Liu, Q., Xu, M. and Wang, Z. (2020), "Inter-annual variability of heavy metals pollution in surface sediments of Jiangsu coastal region, China: Case study of the Dafeng Port", Marine Pollution Bulletin, Vol. 150, p. 110720.

Chen, C.W., Ju, Y.R., Chen, C.F. and Dong, C.D. (2016), "Evaluation of organic pollution and eutrophication status of Kaohsiung harbor, Taiwan", International Biodeterioration and Biodegradation, Vol. 113, pp. 318-324.

Chen, J., Zheng, T., Garg, A., Xu, L., Li, S. and Fei, Y. (2019), “Alternative Maritime power application as a green port strategy: Barriers in China”, Journal of Cleaner Production, Vol. 213, pp. 825-837.

Cheniti, R., Rochon, A. and Frihi, H. (2018), "Ship traffic and the introduction of diatoms and dinoflagellates via ballast water in the Port of Annaba, Algeria", Journal of Sea Research, Vol. 133, pp. 154-165.

Cullinane, K. and Cullinane, S. (2013), "Atmospheric emissions from shipping: the need for regulation and approaches to compliance", Transport Reviews, Vol. 33 No. 4, pp. 377-401.

Darbra, R.M., Pittam, N., Royston, K.A., Darbra, J.P. and Journee, H. (2009), "Survey on environmental monitoring requirements of European ports", Journal of Environmental Management, Vol. 90 No. 3, pp. 1396-1403.

Erdas, C., Fokaides, P.A. and Charalambous, C. (2015), "Ecological footprint analysis based awareness creation for energy efficiency and climate change mitigation measures enhancing the 
environmental management system of Limassol Port”, Journal of Cleaner Production, Vol. 108, pp. 716-724.

Ferdous, R., Khan, F., Sadiq, R., Amyotte, P. and Veitch, B. (2012), "Handling and updating uncertain information in bow-tie analysis", Journal of Loss Prevention in the Process Industries, Vol. 25 No. 1, pp. 8-19.

Ghashat, H.M. and Cullinane, K.P.B. (2013), "The future governance structure of Libya's container ports: a survey of stakeholder attitudes", Research in Transportation Business and Management, Vol. 8, pp. 7-16.

Greiner, M. (2014), “Application of market based instruments for safeguarding water quality in coastal waters: case study Darwin Harbor, Australia”, Journal of Hydrology, Vol. 509, pp. 1-12.

Goyal, R.K., Kaushal, S. and Sangaiah, A.K. (2018), "The utility based non-linear fuzzy AHP optimization model for network selection in heterogeneous wireless networks", Applied Soft Computing, Vol. 67, pp. 800-811.

Hall, P.V., O'Brien, T. and Woudsma, C. (2013), "Environmental innovation and the role of stakeholder collaboration in West Coast port gateway", Research in Transportation Economics, Vol. 42 No. 1, pp. 87-96.

Hua, C., Chen, J., Wan, Z., Xu, L., Bai, Y., Zheng, T. and Fei, Y. (2020), "Evaluation and governance of green development practice of port: a sea port case of China", Journal of Cleaner Production, Vol. 249, 119434, pp. 1-10.

Innes, A. and Monios, J. (2018), "Identifying the unique challenges of installing cold ironing at small and medium ports - the case of Aberdeen", Transportation Research Part D: Transport and Environment, Vol. 62, pp. 298-313.

Klopott, M. (2013), "Restructuring of environmental management in Baltic ports: Case of Poland", Maritime Policy and Management, Vol. 40 No. 5, pp. 439-450.

Ko, T.T. and Chang, Y.C. (2010), "Integrated marine pollution management: a new model of marine pollution prevention and control in Kaohsiung, Taiwan", Ocean and Coastal Management, Vol. 53 No. 10, pp. 624-635.

Lam, J.S.L. and Notteboom, T. (2014), "The greening of ports: a comparison of port management tools used by leading ports in Asia and Europe", Transport Reviews, Vol. 34 No. 2, pp. 169-189.

Lam, J.S.L. and Li, K.X. (2020), "Green port marketing for sustainable growth and development", Transport Policy, Vol. 84, pp. 73-81.

Le, X.Q., Vu, V.H., Hens, L. and Heur, B.V. (2014), "Stakeholder perceptions and involvement in the implementation of EMS in ports in Vietnam and Cambodia", Journal of Cleaner Production, Vol. 64, pp. 173-193.

Linder, A. (2018), "Explaining shipping company participation in voluntary vessel emission reduction programs", Transportation Research Part D: Transport and Environment, Vol. 61, pp. 234-245.

Liu, T.K. and Tsai, T.K. (2011), "Vessel traffic patterns in the port of Kaohsiung and the management implications for preventing the introduction of non-indigenous aquatic species", Marine Pollution Bulletin, Vol. 62 No. 3, pp. 602-608.

Liu, T.K., Chang, C.H. and Chou, M.L. (2014), "Management strategies to prevent the introduction of non-indigenous aquatic species in response to the ballast water convention in Taiwan", Marine Policy, Vol. 44, pp. 187-195.

Liu, J., Yin, Y. and Yan, S. (2019), "Research on clean energy power generation-energy storage-energy using virtual enterprise risk assessment based on fuzzy analytic hierarchy process in China", Journal of Cleaner Production, Vol. 236, 117471, pp. 1-14.

Luna, G.M., Manini, E., Turk, V., Tinta, V., D’Errico, G., Baldrighi, E., Baljak, V., Buda, D., Cabrini, M., Campanelli, A., Cenov, A., Negro, P.D., Drakulović, D., Fabbro, C., Glad, M., Grilec, D., Grilli, F., Jokanović, S., Jozić, S., Kauzlarić, V., Kraus, R., Marini, M., Mikuš, J., Milandri, S., Pećarević, M., Perini, L., Quero, G.M., ŠolićM, M., Lušić, D.V. and Zoffoli, S. (2019), "Status of faecal pollution in 
MABR

6,2 ports: a basin-wide investigation in the adriatic sea”, Marine Pollution Bulletin, Vol. 147, pp. 219-228.

Mellin, A. and Rydhed, H. (2011), "Swedish ports' attitudes towards regulations of the shipping sector's emissions of $\mathrm{CO}_{2}$ ", Maritime Policy and Management, Vol. 38 No. 4, pp. 437-450.

Miluse, T. and Beatriz, T. (2015), "Port-city exhaust emission model: an application to cruise and ferry operations in Las Palmas Port", Transportation Research Part A: Policy and Practice, Vol. 78, pp. $347-360$.

Moeis, A.O., Desrian, F., Destyanto, A.R., Zagloel, T.Y., Hidayatno, A. and Sutrisno, A. (2020), "Sustainability assessment of the Tanjung priok port cluster", International Journal of Technology, Vol. 11 No. 2, pp. 353-363.

Munim, Z.H., Friese, H.S. and Dushenko, M. (2020), "Identifying the appropriate governance model for green port management: Applying analytic network process and Best-Worst methods to ports in the India Ocean Rim”, Journal of Cleaner Production, Vol. 268, pp. 1-13.

Olcer, A. and Ballini, F. (2015), "The development of a decision making framework for evaluating the trade-off solutions of cleaner seaborne transportation", Transportation Research Part D: Transport and Environment, Vol. 37, pp. 150-170.

Peng, Y., Li, X., Wang, W., Wei, Z., Bing, X. and Song, X. (2019), “A method for determining the allocation strategy of on-shore power supply from a green container terminal perspective", Ocean and Coastal Management, Vol. 167, pp. 158-175.

Rastmanesh, F., Mousavi, M., Zarasvandi, A. and Edraki, M. (2017), "Investigation of elemental enrichment and ecological risk assessment of surface soils in two industrial port cities, southwest Iran”, Environmental Earth Sciences, Vol. 76 No. 20, p. 717, available at: https://doi. org/10.1007/s12665-017-7046-2

Rossi, R., Gastaldi, M. and Gecchele, G. (2013), "Comparison of fuzzy-based and AHP methods in sustainability evaluation: a case of traffic pollution-reducing policies", European Transport Research Review, Vol. 5 No. 1, pp. 11-26.

Sany, S.B.T., Salleh, A., Sulaiman, A.H., Sasekumar, A., Rezayi, M. and Tehrani, G.M. (2013), "Heavy metal contamination in water and sediment of the Port Klang coastal area, Selangor. Malaysia", Environmental Earth Sciences, Vol. 69 No. 6, pp. 2013-2025.

Saaty, T.L. (1980), The Analytic Hierarchy Process, McGraw-Hill, New York, NY.

Sahin, B. and Yip, T.L. (2017), "Shipping technology selection for dynamic capability based on improved Gaussian fuzzy AHP model", Ocean Engineering, Vol. 136, pp. 233-246.

Satir, T. (2014), "Ballast water treatment systems: design, regulations, and selection under the choice varying priorities", Environmental Science and Pollution Research, Vol. 21 No. 18, pp. 10686-10695.

Subasi, E. and Dogan-Saglamtimur, N. (2013), "Performance evaluation of the Martas Port waste reception facility treatment plant (Tekirdag, Turkey)", Desalination and Water Treatment, Vol. 51, pp. 13-15.

Tsai, Y.T., Liang, C.J., Huang, K.H., Hung, K.H., Jheng, C.W. and Liang, J.J. (2018), “Self-management of greenhouse gas and air pollutant emissions in Taichung Port, Taiwan", Transportation Research Part D: Transport and Environment, Vol. 63, pp. 576-587.

Tseng, P.H. and Pilcher, N. (2015), "A study of the potential of shore power for the port of Kaohsiung, Taiwan: to introduce or not to introduce?", Research in Transportation Business and Management, Vol. 17, pp. 83-91.

Tseng, P.H. and Pilcher, N. (2016), "Exploring the viability of an emission tax policy for ships at berth in Taiwanese ports", International Journal of Shipping and Transport Logistics, Vol. 8 No. 6, pp. 705-722.

Tseng, P.H. and Cullinane, K. (2018), "Key criteria influencing the choice of arctic shipping: a fuzzy analytic hierarchy process model", Maritime Policy and Management, Vol. 45 No. 4, pp. 422-438. 
Tseng, P.H. and Pilcher, N. (2019), "Evaluating the key factors of green port policies in Taiwan through quantitative and qualitative approaches", Transport Policy, Vol. 82, pp. 127-137.

Wang, Y.M., Luo, Y. and Hua, Z. (2008), "On the extent analysis method for fuzzy AHP and its applications", European Journal of Operational Research, Vol. 186 No. 2, pp. 735-747.

Wang, C., Zhang, D., Yang, X. and Yang, Z. (2018), "A novel model for the quantitative evaluation of green port development a case study of major ports in China", Transportation Research Part D: Transport and Environment, Vol. 61, pp. 431-443.

Wang, X., Shen, Y., Lin, Y., Pan, J., Zhang, Y., Louie, P.K.K., Li, M. and Fu, Q. (2019), “Atmospheric pollution from ships and its impact on local air quality at a port site in Shanghai", Atmospheric Chemistry and Physics, Vol. 19 No. 9, pp. 6315-6330.

Zadeh, L.A. (1965), "Fuzzy sets", Information and Control, Vol. 8 No. 3, pp. 338-353.

Zhen, L., Li, M., Hu, Z., Lv, W. and Zhao, X. (2018), "The effects of emission control area regulations on cruise shipping", Transportation Research Part D: Transport and Environment, Vol. 62, pp. 47-63.

Zhou, Y., Zhang, Y., Ma, D., Lu, J., Lou, W., Fu, Y., Li, S., Feng, J., Huang, C., Ge, W. and Zhu, H. (2020), "Port-Related emissions, environmental impacts and their implication on green traffic policy in Shanghai", Sustainability, Vol. 12 No. 10, pp. 1-17, doi: 10.3390/su12104162.

Zhu, M., Yuen, K.F., Ge, J.W. and Li, K.X. (2018), "Impact of Maritime emissions trading system on fleet deployment and mitigation of $\mathrm{CO}_{2}$ emission", Transportation Research Part D: Transport and Environment, Vol. 62, pp. 474-488.

\title{
Further reading
}

Peng, Y., Liu, H., Li, X., Huang, J. and Wang, W. (2020), "Machine learning method for energy consumption prediction of ships in port considering green ports", Journal of Cleaner Production, Vol. 264, pp. 121564-121514.

Wang, Y., Jung, K.A., Yeo, G.T. and Chou, C.C. (2016), "Selecting a cruise port of call location using the fuzzy-AHP method: a case study in East Asia", Tourism Management, Vol. 42, pp. 262-270.

\begin{abstract}
About the authors
Po-Hsing Tseng is currently an Assistant Professor in the Department of Shipping and Transportation Management of National Taiwan Ocean University in Taiwan. He received his BBA, $\mathrm{MBA}$ and $\mathrm{PhD}$ from the Department of Transportation and Communication Management Science of National Cheng Kung University in Taiwan. Dr Tseng's current research interests include shipping management and green port operations and management. He has contributed 20 articles to professional journals such as Maritime Business Review, Transport Policy, Maritime Policy and Management, Transport Policy, International Journal of Sustainable Transportation, Transportation Research Part D, International Journal of Shipping and Transport Logistics and International Journal of Logistics Management. Po-Hsing Tseng is the corresponding author and can be contacted at: phtseng@mail.ntou.edu.tw

ManWo Ng is an Associate Professor in the Department of Information Technology and Decision Sciences in the Strome College of Business at Old Dominion University, USA. He received his $\mathrm{PhD}$ in Transportation from The University of Texas at Austin. He also holds an MS in Statistics from The University of Texas at Austin, an MSc in Applied Mathematics and a BSc in Mechanical Engineering, both from Delft University of Technology, The Netherlands. Dr Ng serves on the Editorial Board of several journals, including Maritime Business Review. He has authored 70+ research articles that have appeared in academic journals and conferences proceedings.
\end{abstract}

For instructions on how to order reprints of this article, please visit our website:

www.emeraldgrouppublishing.com/licensing/reprints.htm

Or contact us for further details: permissions@emeraldinsight.com 